\title{
Beate Hermelinよ お前もか
}

裸の王様達のボスも、これまた裸だった

山口誠

(東京大学)

去年「査読で間違えた Killeenさん」の話をした。結局彼は 自身の最新の JEP 論文でその論文を引用しているのである。 後で top journal で引用することになる論文を閒違ってリジェ クトするのは無駄だと思うが、一方で間違いを認めて引用し た潔さも注目される。去年述べたようにサバンの研究者（裸 の王様達）にはそんな潔さはない。

また去年いきさつを書いたサバンの素数関連能力の論文を アクセプト後に自閉症研究のリーダーFrancesca Happe に送っ たところ、"extremely interesting article"と評し、他の研究者に も見せるようにと言って研究者の連絡先を教えてきた。単な る社交辞令で他人の連絡先を教えるほじ失礼な人とは考えに くいので、やはり本当に分野の研究者に必読と思ったのであ ろう。トップ研究者が必読と見な寸論文を少数の利害関係者 (間違いだらけの裸の王様と掲破された人)が長期間掲載阻止 したなんてことは責任を問われなければならない。無責任な 査読ならしないほうがいい。

ここから本題。昨年サバンと素数に関する Beate Hermelin (1919-2007)らの論文を、実験デザインもデータ表示もおかし く、レベルが極めて低いと評した。しかしなにしろ数十年に わたり分野をリードした人である。少数の論文で判断するの はいかがなものか、きっと本当は優秀な研究者に違いないと 言う人もいるであろう。その答えを彼女の集大成の著書 Bright Splinters of the Mind (2001)に発見した。

素数に関し解説があり、“Fermat が証明なしで書き残し、 後にオイラーが苦心の末、遂に証明した定理” なるもの（と 数值例）を以下のように紹介していた：

・素数は全て $4 \mathrm{n}+1$ か $4 \mathrm{n}-1$ の形である。

例 : $13=4 \cdot 3+1 、 19=4 \cdot 5-1$ 。ほらね!

ちょっと、あなた！！4n, 4n+2 は偶数なんだから、素数は (2 以外）残りの $4 \mathrm{n}+1$ か $4 \mathrm{n}-1$ に決まってるでしょうが!この 人は一体何を言っているのでしょうか！? 証明はオイラーが 世に現れるまで待たねばならなかったなんてはずがないでし よう。こんな当たり前の命題は普通は定理とは言わない。せ いぜい Hermelinの珍定理だ。Fermat・オイラーとくれば、こ れは以下の「Fermat の二平方和の定理」のことだ：

- $4 \mathrm{n}+1$ の形の素数は二整数の二乗の和と表せ、 $4 n-1$ の形の 素数はそう表せない。

例 : $13=2^{\wedge} 2+3 \wedge 2 、 19$ は表せない。 全然違う。

間違いの原因は寸ぐわかった。同じ数值例が出ているので 間違いない。Fermat の大定理に関するサイモン・シンの世界 的大ベストセラー読み物である。確認すると、彼は素数は $4 n+1$ か $4 n-1$ であることを述べた後、その同じ段落でちゃん と二平方和定理を説明しているのである。一般向けの読夕物 をまともに理解できず、書き写し間違えるような人であった のか。ソーカル事件（知の欺瞞）を思い出す。こんな人だか らおかしい論文を書いたのであろう。(なお、あくまでシンは 読み物であり、数学的記述は所及不正確である。)

心理学者にこんな定理の知識が必要だと言っているのでは なく、しかし Hermelinの珍定理ではおかしいと思う知性は必 要でしょう。また素数に関する研究をするのなら、読み物で なく教科書を読む（そして理解する）べきであろう。これで はそこらの中学生と変わらないではないか。こんな人がずっ
と分野のリーダーで、おそらく査読も数えられないほどした ことであろう。しかも調べればわかるように、サバンの研究 者は大半が Hermelin と関係がある（連名で論文を書いている 等) のである!

自分の論文では例えば一部のサバンの文献（以下参照）で も紹介されている素数判定法の Fermatテストについて、 $\mathrm{a}^{\wedge}(\mathrm{n}-1) \equiv 1 \bmod \mathrm{n}$ の抽象的形だけでなく具体的に計算が見え るように、表計算ソフトでの実行法を解説したのである。こ の分野の人たちに査読させたのは、中学生に大学の教科書を 渡して審査してくれと言ったのと同じことであったであろう。 どうやって查読に通る（彼らに理解させる）のか。查読制度 自体に否定的なのではなく、中学生が査読するくらいなら、 しないほうがいいと言っているのである。こんなにレベルの 低い分野は查読制ではなく人文系と同じシステムでやればい い。おかしい論文が査読を通りそれを正す論文が阻止される より、とりあえず査読なしでみな掲載しておけば、わかる人 にはわかるのであるから。実験心理学が特別レベル高いとは 思わないが、さすがにこれとは比較にならない。分野の世界 的リーダーがこのレベルということはありえない。

また Hermelin とは関係ないが別の研究者 Matthysse \& Greenberg (1988)がサバンの素数能力について解説している のを見つけたが、やはり真に理解している人ではなかった（ま たかよ)。Fermat テストの限界を示す Carmichael 数について 解説していたのだが、561(=3・11・17)を例に $2^{\wedge} 560 \equiv 1 \bmod 561$, $3^{\wedge} 560 \equiv 1 \bmod 561,4 \wedge 560 \equiv 1 \bmod 561$ ・・などと書いている がウソである。Carmichael 数は一般向けの読み物には「いつ でも素数のふりをする」くらいに書いてあるものもあるだろ らから鵜吞みにしたのであろうが、厳密には底(a)が法(n)と互 いに素であるときだけ Fermat テストを通るのである。事実、 底 3 では 1 に合同にならず $3^{\wedge} 560 \equiv 375 \bmod 561$ である。代数 的には、法と互いに素である元（「既約剩余系」）だけ逆元が 存在するということだが、高校数学レベルでも簡単なことで ある。 modular 算術の書き方でなく初心に帰って高校生にも わかる書き方をすると、3^560は 3 草いてしまうと、 $\bmod$ 561 で剩余を考えるとは何らかの $\mathrm{m}$ をもってきて $3 \mathrm{n}-561 \mathrm{~m}$ の形にすることであり、561=3・187 なので結局 3(n-187m) になり、従って決して 1 にはならない（常に 3 の倍数）ので ある。理解せずに本を書き写したのであろう。

ここまで読んで、このような数論や (抽象) 代数学の話は ごく一部を除いた大多数の心理学者には全く関係ないこと、 と思った人もいるであろうが、必ずしもそうでもない。Piaget も代数系を取り上げている。もっとも彼の代数・論理学はだ いぶいい加減なものであることが既に指摘されている(『ピア ジェの認識心理学』(波多野) を見よ)。また日本でも特集号 が組まれ広く知られている行動分析学の刺激等価性で「反射 律・対称律・推移律」と同值類の概念が使われているが、最 良の例の一つは整数の剰余類である。人類学の Levi-Strauss の群論も有名である。

本稿を読んで「嫌味なことばっか言うなあ」としか思わな い人もいるであろうが、優秀な方は研究のチャンス、日本主 導で教科書を書き換えるチャンスを見るであろう。一人で裸 の王様達を相手にするのは全く得策ではないが、ある程度集 まれば可能であろう。やる気のある人がいれば協力する。 